\title{
PROTECTION AND CONTROL OF THE ENVORMENT
}

\section{Madhukar Sonune}

Shri. Shivaji Science \& Arts College, Tq-Chikhli, Dist- Buldhana, Pin-443201, Maharashtra, India

Corresponding author Email : mbsonune@gmail.com

\begin{abstract}
:
Pollution is not entirely symbolic of industrial and economic development but can also be indicative of poor technologies, poverty and large population. We are confronted today with rising demands as also the most basic needs of a population, growing not only in size, but also in awareness, on the one hand, and a rapid rate of depletion of our natural resource base on the other. The world as well as India realised that application of science and technology, without assessing its far reaching and global consequences, posed progressively greater threats to the planet's environment and ultimately on causing adverse impact on human health \& biodiversity. The physio -chemical effect of various types of pollutants on air, water, soil \& human health can be minimised with the effective implementation of the legislative and regulatory measures which have been developed aim at preservation, conservation and protection of the environment.
\end{abstract}

\section{Keywords:}

Pollutants, global warming, environment, green house effect, natural resource, biodiversity, health, disease, acts.

\section{Introduction:}

Earth is the only known place in the universe that can support human life. It is very important that we realize this fact and take very good care of our mother planet. In this modern edge of technology, the industrialization \& economic developmental activities creating the various environmental problems. Environment pollution is a worldwide problem and its potential to influence the health of human populations is great (Fereidoun et al, 2007; Progressive Insurance, 2005.). Human exposure to pollution is believed to be more intense now than at any other time in human existence (Schell et al, 2006). There is no doubt that excessive levels of pollution are causing a lot of damage to human $\&$ animal health, plants $\&$ trees including tropical rainforests, as well as the 
wider environment. (Tropical Rainforest Animals, 2008). Due to green house effect \& global warming the environmental conditions are rapidly changing in India. Indian cities, among the most polluted cities are in the world. (Carter, 1985). The outdoor and indoor air pollutants, water shortages and pollution, desertification and soil pollution, have become more pronounced and are subjecting human race to significant health risks. Environmental pollution is tangled with the unsustainable anthropogenic activities, resulting in substantial public health problems. (Khan, 2004). It's difficult to watch the environment affecting human health and not feel spurred to change The health status of an individual, a community or a nation is affected by the interplay and integration of two types of environment-the internal environment of man himself and the external environment which surrounds him.

\section{Material and Method:}

Types of pollution:

Air pollution

- Water pollution

- Soil pollution

- Noise pollution

- Marine pollution

- Thermal pollution

- Nuclear hazards The health hazards effects on human:

It's difficult to watch the environment affecting human health and not feel spurred to change The health status of an individual, a community or a nation is affected by the interplay and integration of two types of environment-the internal environment of man himself and the external environment which surrounds him. The internal environment pertains to "each and every component part, every tissue, organ and organ system and their harmonious functioning within the body system". The health status of man is the outcome of a continual adjust $\neg$ ment and readjustment between the internal and 
external environment. Air pollution results are Cancer ( Ries et al. 1999; European Public Health Alliance, 2009), neurobehavioral disorders , cardiovascular problems, reduced energy levels (Colls, 2002), premature death, asthma, asthma exacerbations (D'Amato et al, 2005; Heinrich \& Wichmann, 2004; Künzli et al, 2000; Nel, 2005;) headaches and dizziness, irritation of eyes, nose, mouth and throat; reduced lung functioning; respiratory symptoms (Colls, 2002; Vichit-Vadakan, 2001), respiratory disease, disruption of endocrine, and reproductive and immune systems (Colls, 2002; European Public Health Alliance, 2009). High air pollution levels have been linked to infant mortality. (Fereidoun et al, 2007). Air pollutants can also indirectly affect human health through acid rain, by polluting drinking water and entering the food chain, and through global warming and associated climate change and sea level rise. (Mishra, 2003). Polluted drinking water or water polluted by chemicals produced waterborne diseases like, Giardiasis, Amoebiasis, Hookworm, Ascariasis, Typhoid, Liver and kidney damage, Alzheimer's disease, non-Hodgkin's Lymphoma, multiple Sclerosis, Hormonal problems that can disorder development and reproductive processes, Cancer, heart disease, damage to the nervous system, different type of damages on babies in womb, Parkinson's disease, Damage to the DNA and even death, meanwhile, polluted beach water contaminated people like stomach aches, encephalitis, Hepatitis, diarrhoea, vomiting, gastroenteritis, respiratory infections, ear ache, pink eye and rashes (Water Pollution Effects, 2006).

\section{Result and Discussion}

Prevention and Control of Pollution : Government have been developed some important legal instruments for preservation, conservation and protection of the environment $\&$ human health are

- Wildlife (Protection) Act, 1972

- Water (Prevention and Control of pollution) Act,1974 - Forest

Conservation Act, 1980 
-

Air (Prevention and Control of pollution) Act,1981 • Environment (Protection) Act, 1986

Public Liability Insurance Act, 1991

- National Environment Tribunal Act, 1995

- National Environment Appellate Authority Act,1997

All the necessary steps are included in these instruments sufficient to curb the disastrous ill effect of all type of environmental pollutants on biodiversities.

\section{Conclusion:}

Health hazards are caused due to lack of pro $\neg$ per harmony between man and his environments. Man is living in a highly complicated environment which is getting more complicated as man is becoming more ingenious. Thus the problems of pollution $\&$ effect on human health as also, because of depleting resources, have to keep in view the people and their numbers, their aspirations, economic standing, literacy, all in the context of international trade and international obligations. We need time-bound programmes that entail coordinated interdepartmental strategies. It envisages control of pollution from various sources such as Industrial, domestic, vehicular, agricultural and noise. The basic principle that it seeks to establish is of prevention of pollution, rather than treatment at the end of line and therefore strives for the use of cleaner technologies, appropriate sitting of industries, use of cleaner fuels, resource-efficient and energy-efficient technologies, along with regular monitoring of air and water quality, inventorisation and proper disposal of hazardous waste, and above all creation of public awareness.

\section{Acknowledgement:}

Author is much thankful to principal, Shri Shivaji Science \& Arts College, Chikhli, Dist. Buldana for providing necessary laboratory facilities. 


\section{Reference:}

Ashraf, M. A., Maah, M. J., Yusoff, I. \& Mehmood, K. (2010). Effects of Polluted Water Irrigation on Environment and Health of People in Jamber, District Kasur, Pakistan, International Journal of Basic \& Applied Sciences, 10(3), pp. 37-57.

Avdeev, O. \& Korchagin, P. (1994). Organization and Implementation of Contaminated Waste Neutralization in the Ukraine - National Report II, Central. European Journal of Public Health, (suppl), pp. 51-52.

Blaxill, M. F. (2004). What's going on? The Question of Time Trends in Autism. Public Health Reports, 119(6), pp. 536-551.

Brauer, M., Hoek, G., Smith, H. A., de Jongste, J. C., Gerritsen, J. \& Postma, D. S. (2007). Air Pollution and Development of Asthma, Allergy and Infections in a Birth Cohort, European Society for Clinical Respiratory Physiology, 29(5), pp. 879-888.

British Airways, (1993), Annual Environment Report, London: British Airways plc, Environment Branch, Heathrow.

Carter, F. W. (1985). Pollution Problems in Post-War Czechoslovakia, Transactions of the Institute of British Geographers, 10(1), pp. 17-44.

Ciocco, A. \& Thompson, D. J. (1961). A Follow-up on Donora Ten Years After: Methodology and Findings, American Journal of Public Health, 51(2), pp. 155- 164.

Colls, J. (2002). Air Pollution. New York: Spon Press.

Crisp, T. M., Clegg, E. D., Cooper, R. L., Wood, W. P., Anderson, D. G., Baetcke, K. P., Hoffmann, J. L., Morrow, M. S., Rodier, D. J., Schaeffer, J. E., Touart, L. E., Zeeman, M. G. \& Patel, Y. M. (1998). Environmental Endocrine Disruption: An Effects Assessment and Analysis, Environmental Health Perspectives,106(1), pp. 11-56 
Cucu. M., Lupeanu, M. I., Nicorici, M., Lonescu, L. \& Sandu, S. (1994). The Dangerous Wastes and Health Risks in Romania: National Report, Central European Journal of Public Health, 2(suppl), pp. 41-43.

D'Amato, G., Liccardi, G., D'Amato, M. \& Holgate. S. (2005). Environmental Risk Factors and Allergic Bronchial Asthma, Clinical \& Experimental Allergy, 35(9), pp.1113- 1124.

DeBarteleven, J. (1992). Eastern Europe's Environmental Crisis. Baltimore, MD: Johns Hopkins Press

European Public Health Alliance, (2009). Air, Water Pollution and Health Effects. Retrieved from http://www.epha.org/r/54

Mishra, V. (2003). Health Effects of Air Pollution, Background paper for Population- Environment Research Network (PERN) Cyberseminar, December 1-15. Retrieved from http://www.mnforsustain.org/climate_health_effects_of_air_pollution_mi s hra_pern.htm

Rushbrook, P. (1994). Regional Health Issues Related to Hazardous Wastes, Central European Journal of Public Health, 2(suppl), pp. 16-20.

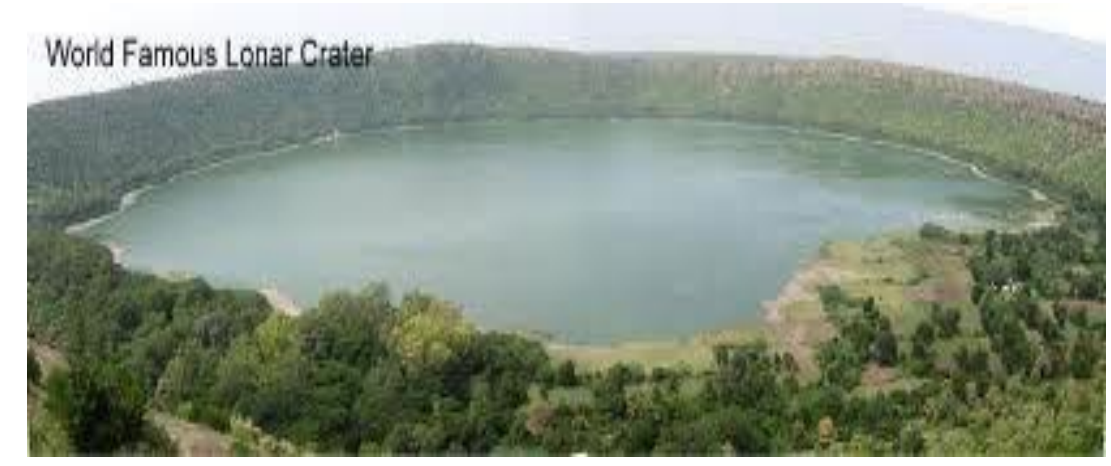

